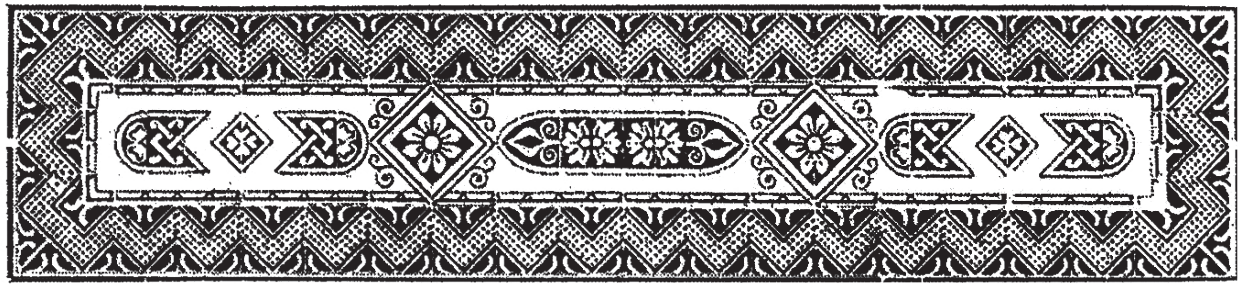

doi https://doi.org/10.18485/bratstvo.2020.24.4 УДК 929.7(497.6)

Рад примљен: 06.09.2020.

Рад прихваћен: 16.09.2020.

Оригиналан научни рад

\title{
ПЛЕМСТВО СЕВЕРОИСТОЧНЕ БОСНЕ
}

У прилогу о племству североисточне Босне у средњем веку пажња се скреће на родове који су се истииали у одржаваьу православне вере и наиионалног осећања. Међу њима посебно су се истицали Тихорадићи, челник Хлап и његови потомци, Златоносовићи, Ковачевићи.

Од првог помена града Салинеса у десетом веку који је тада припадао крштеној Србији, североисточна Босна, земље Усора и Соли, мењала је владаре и прелазила из једне у другу државу. Овим простором средином десетог века управљао је Часлав Клонимировић, затим мађарски краљеви, српски краљ Драгутин и српски деспот Стефан Лазаревић и Ђурађ Бранковић, босански банови и краљеви, све до доласка Турака. У тим честим променама једино се у православној вери и народноном осећању одржавало источнобосанско племство међу којим су се највише истицали Тихорадићи, преци и потомци челника Хлапа, Златоносовићи, Ковачевићи, који су, исповедајући православну веру, наручивали јеванђеља рађена према канонима православне цркве, учествовали 1389. године са кнезом Лазаром у Косовском боју, подизали са својим православним владарима цркве и манастире.

Наслеђе немањићке државе краља Драгутина и православну веру Српске цркве чувало је и племство североисточне Босне. У историјским изворима и владарским повељама помиње се бројна властела „земаља“ Усоре и Соли, ${ }^{1}$ а уз њихова имена навођене су и њихове титуле: војводе,

1 У повељама босанских владара и другим државним документима поједине жупе, области, историјско-географске целине називају се „земље“, па се тако и за Усору и Соли 
челници, кнезови, жупани. ${ }^{2}$ Те титуле представника власти срећу се и у немањићкој држави, али и у Српској деспотовини. ${ }^{3}$

Једна рукописна књига из прве половине четрнаестога века, позната као Дивошево јеванђеље, скренула је пажњу на усорски род Тихорадићи, чији је истакнути предак био жупан Тихорад. ${ }^{4}$ Властелински посед, жупа жупана Тихорада захватала је просторе Мајевице у чијем су се средишту налазила села Тошино или Подлистина, Лопаре, Прибој, Тобуд, Лабуцка, Липовица, Врановићи (Вранићи). Овај простор чији су централни део захватала поменута села у средњем веку се звао Заврш или Завршје, које је захватало знатно шири простор. ${ }^{5}$ Иза жупана Тихорада остали су његови синови Витан и Дивош Тихорадић који се помињу у једној повељи босанског бана Стефана II Котроманића. ${ }^{6}$ Браћа Тихорадићи помињу се и у још једној повељи истога владара од 15. маја 1333. године где је за Дивоша записано да је пристав, (управитељ, заступник владарских имања, или, можда, заступник извршне власти). ${ }^{7}$

Дивошево јеванђеље пронађено 1960. године у православној сеоској цркви у селу Подврху код Бијелог Поља у Старој Херцеговини, ${ }^{8}$ могло је бити преписано око 1330. године. ${ }^{9}$ Данас се чува у Музеју Митрополије црногорско-приморске на Цетињу. ${ }^{10}$ Ова богослужбена књига рађена је

каже да су „земље“ Термин „земље“ Усора и Соли усталио и у стручној литератури.

2 У свом попису војвода Усоре и Соли Павао Анђелић наводи Белошевиће, Треботиће, Дињчиће, Тихорадиће, Златоносовиће, Станчиће, род усорског властелина челника Хлапа, Анђелић, Студије о територијалнополитичкој организацији средњовјековне Босне, Сарајево, 1982, 142-172.

3 Војводе су у Деспотовини били првенствено војни заповедници, поред великог војводе, који је био уз владара постојале су и војводе у унутрашњости државе, у жупама и „земљама“. Они су поред војне, у извесној мери, имали и цивилну власт. Били су заповедници тврђава и њихова седишта била су у тврђавама. Челници су били директни заступници владара у цивилним и судским пословима, а често су се јављали и као судије. Свако веће место имало је кнезове, били су то углавном угледни људи који су се бавили управним пословима, учествовали у суђењима, у њиховим рукама била је извршна власт, пред њима су склапани уговори. Момчило Спремић, Деспот Ђурађ Бранковић и његово доба, Београд, 199, 722, 724-725, 727.

4 Јелена Мргић, Северна Босна 13. до 16. век, Београд, 2008, 89.

5 Мргић, 70; Милош Благојевић, Босанско Заврије, Зборник Филозофског факултета у Београду, 14 - 1, Београд, 1979, 138-139.

6 Мргић, 71.

7 Исто, 72.

8 Јелица Ђурић и Рајка Иванишевић, Јеванђеље Дивоша Тихорадића, Зборник радова Византолошког института, књ. 7, Београд, 1961, 153.

9 Исто, 157.

10 „Рукопис без корица, без почетка и краја, писан је на чврстом пергаменту; листови су формата 16,5 x 22,5 цм. Кватериони од осам листова прошивени су танким канапом... Текст је писан тамнокестењастим мастилом, почеци глава писани су црвеним мастилом. 
по обрасцу источне цркве. ${ }^{11}$ Реч је дакле о православној богослужбеној књизи и због православних канона по којима је рађена не може се користити у католичкој, као ни једној другој псеудохришћанској цркви. Преписана је са предлошка са кога је преписано и Мирослављево јеванђеље, према обрасцима православне цркве. ${ }^{12}$ За шест векова, од настанка па до његовог открића 1960. године, Дивошево јеванђеље преношено је из цркве у цркву, из манастира у манастир, где је стално било у рукама свештенослужитеља у време богослужења.

Велможе земаља Усоре и Соли, као што су то чинили феудалци у српској средњовековној држави Немањића, наручивали су за себе скупоцена јеванђеља која су им преписивали, украшавали и илустровали најгласовитији преписивачи. ${ }^{13}$ Зна се и име преписивача Дивошевог јеванђеља, он се звао Манојло Грк, а од његових књига сачували су се и делови, тридесетак листова, Манојловог (Мостарског) јеванђеља. ${ }^{14} \mathrm{Ha}$ једном од сачуваних листова нашао се и запис, где дијак Манојло Грк саопштава да је поред њега, док је он писао, седео један од господара Соли, челник Хлап. ${ }^{15}$ Овај податак наводи на закључак да је у овим крајевима, негде у некој цркви или манастиру, или на двору неког властелина била преписивачка радионица дијака Манојла Грка. ${ }^{16}$ И Јелена Мргић убеђена је да би наручилац Манојловог (Мостарског) јеванђеља могао бити челник Хлап ,jер је писар Манојло оставио запис у коме каже да је Хлап био код њега док је писао. С обзиром на блиско суседство Усоре и Соли, могло би се помишљати да је ова [преписивачка радионица] била смештена на том простору. Поручивање илуминираних рукописа било је

Њим се служи преписивач када и у натписима на маргинама и у тексту када нарочито жели да истакне неко место. На пуним листовима текст је писан у двадесет два реда... Од свих, до сада познатих, ћирилских, босанских пергаментских рукописа, Дивошево јеванђеље се одликује лепотом стилског украса. Сме се рећи да је оно данас главни споменик босанског минијатурног сликарства. У Дивошевом јеванђељу сачувало се преко шездесет иницијала и једна заставица“, Исто, 153-155.

11 Драгољуб Драгојловић, Историја српске књижевности у средњовековној босанској држави, Нови Сад, 1997, 60.

12 Јово Бајић, Бошьаштво без корена (разговор са др Драгољубом Драгојловићем, научним саветником Балканолошког института САНУ), Експрес - недељна ревија, 21. април, 1991, 14.

13 Нека од тих јеванђеља сачувана су до наших дана, а међу њима и Мирослављево и Вуканово јеванђеље из немањићке Србије, или јеванђеље написано за обласног господара херцега Хрвоја Вукчића, познато под именом Хвалов зборни као и Баталово јеванђеље, преписано за тепчију Батала Шантића

14 Драгојловић, Историја српске књижевности у средњовековној босанској држави, $58-59$.

15 Драгојловић, 59; Мргић, 68.

16 Војислав Ј. Ђурић, Уметност у Босни између јадранских градова и Србије, Историја српског народа, II, 357; Мргић, 68-69. 
обележје статуса високе властеле, што допушта закључак да су усорске и солске велможе били довољно имућни да своје духовне и културне потребе задовоље на овај начин. “17 Манојлово (Мостарско) јеванђеље, према Драгољубу Драгојловићу, написано је „на пергаменту уставним типом ћирилице првих деценија XIV века. Од оштећеног рукописа сачувано је само 32 листа који садрже одломке Матејевог, Марковог и Лукиног еванђеља.“ 18

Дивошевим јеванђељем и преписивачким радом дијака Манојла Грка бавили су се лингвисти, историчари и историчари уметности, а међу њима и историчар уметности академик Војислав J. Ђурић који каже: „Уметнички украс у Манојловим рукописима, од којих је нешто старије Мостарско јеванђеље, скоро да је јединствен по програму, употреби заставица и иницијала као јединих мотива, као и по стилским својствима, мада није дело једног уметника. Мостарско јеванђеље је украшено много сиромашније. Остале су само две заставице с преплетеним тракама и круговима, неколико мањих иницијала с 'крилцима' и један са девојком у дугој хаљини, која се придржава за биљку. Све је то само танко прекривено бојом, већином црвеном, жутом и плавом. Цртачка невештина је очигледна, а присуство романичког изгледа фигуре и предлошка за заставице и иницијале из српских рукописа XIII века неоспорно.

Множина иницијала у Дивошевом јеванђељу и разноврсност њихових мотива далеко надмашује украс у другим босанским књигама из XIV столећа. Готово да нема странице у којој се не налазе, а заузимају истакнуто место, јер обично по висини прелазе десет редова исписаног текста. Ређи је иницијал образован помоћу преплетених трака, разлистаних и расцветаних грана или змија, а много чешћи са представљеним псима, змајевима, птицама и људима. Некада су животињске и људске фигуре приказане саме, и тада држе, односно кљују или прождиру биљку, а други пут су у паровима, симетрично постављене. Има доста представа из нестварног света: два бића урасла доњим деловима тела у неко стабло, биљку, шарени стубић; људске фигуре с телом неке фантастичне животиње или биљке; зверка која се преображава у растиње; двоглави орлови или фантастичне немани. Увек је тражен такав композициони склоп који би омогућио читљивост почетног слова. Сликар Дивошевог јеванђеља се типом иницијала надовезао на јужнословенску минијатуру из ћирилских књига XIII века, али је успео да створи свој језик. Осећање за декоративност било му је веома развијено: унутар основног, најчешће црвеног цртежа, помно је извлачио шаре - украшавао одела људи, перје птица, крљушти и крзно звери - и равномерно нанесеном бојом прекривао неке њихове делове, остављајући и пергаментној подлози да

17 Мргић, 68-69.

18 Драгојловић, 58-59. 
дође до изражаја. Његови иницијали држе се на уравнотеженом односу светлих, црвених и зелених боја; готово изузетно се уз њих нађе и жута."

Дивошево и Манојлово јеванђеље, као и сва босанска јеванђеља, писано је по православним канонима и, како каже Драгојловић, све те библијске књиге су „без изузетка, кодиколошки и литургијски конципиране према изворницима источне цркве““. ${ }^{20}$ Али и остали ћирилични средњовековни босански текстови (егзегетски, хагиографски, хомилитички и литургијскообредни) „припадају источном огранку јужнословенске књижевности“. ${ }^{21}$

Савременик Дивоша Тихорадића из Завршја, челник Хлап из „земље“ Соли, помиње се као сведок „од Соли“ у повељама бана Стјепана II Котроманића издатим $1326,1329$. и 1332 . године. ${ }^{22}$ Занимљива је и титула челник ${ }^{23}$ коју је он носио. У титули челник, како сматра Павао Анђелић, „треба гледати утицај српске управно-политичке терминологије која је у овој области била уведена за вријеме Стефана Драгутина Немањића и његовог сина Владислава.“24

У повељама бана Стјепана II Котроманића из 1326 и 1329. године, међу сведоцима, уз име челника Хлапа јавља се и име још једног властелина из Соли, жупана Будоша, који је, судећи по звању жупан, припадао старом властеоском роду. Титулу жупана носили су најистакнутији представници старих племенских родова који су се налазили на челу жупа, мањих географско-административних целина као што је жупа Соли, који су имали поседе у тој жупи. Они су, захваљујући своме угледу, усмеравали целокупни живот у својој жупи и у неку руку надзирали цивилну и војну власт. ${ }^{25}$ Жупан Будош ${ }^{26}$ и челник Хлап, како сматра Павао Анђелић припадали су истом племићком роду. ${ }^{27}$

У историјским изворима помињу се четири сина челника Хлапа. У владарској повељи из 1333. године, међу сведоцима, помињу се двојица Хлапових синова, Радослав Хлаповић и Шћитко Хлаповић који има звање

19 Ђурић, Исто дело, 356-357.

20 Драгојловић, 22.

21 Драгојловић, 69.

22 Анђелић, Исто дело, 170; Мргић, 71.

23 Челник је старо звање из времена немањићке Србије, а задржало се и у време деспота Стефана и Ђурђа Бранковића. Челници су били државни службеници који су заступали владара у војним и цивилним пословима на нивоу државе, али и њених административних јединица. У Деспотовини су челници бивали и судије, Момчило Спремић, Деспот Ђурађ Бранковић и юегово доба, Београд, 1994, 723.

24 Анђелић, 142.

25 Благојевић, 23-26, 43.

26 У једној владарској повељи из 1332. године, на списку сведока, иза челника Хлапа, записано је и име Ивана Будисалића. Павао Анђелић закључује да би то могао бити син жупана Будоша, Анђелић, 170.

27 Анђелић, 170. 
пристава. ${ }^{28}$ У владарским повељама из 1345. и 1351. године јавља се име Прибислава Хлаповића, који би могао бити трећи син челника Хлапа. У повељи из 1351. године међу сведоцима из Усоре поменут је као Прибислав Хлапотић. ${ }^{29}$ Име четвртог Хлаповог сина Стипоја Челничића остало је запамћен захваљујући сачуваним владарским повељама из 1345, 1351. и 1367. године, у повељи из 1367. наведено је да он поред звања пристава носи титулу казанца ${ }^{30}$ што је важно државно звање. ${ }^{31}$ У повељама из 1351. и 1367. помиње се име унука челника Хлапа, Поручена Прибиславића, сведока из Усоре. ${ }^{32}$ Поручен Прибиславић био је син трећег Хлаповог сина, Прибислава Хлаповића. У другој повељи сазнајемо да је он носио титулу жупана коју је својевремено имао и солски жупан Будош. Пошто је титула жупана била наследна Павао Анђелић закључује да су Хлаповићи из рода жупана Будоша. ${ }^{33}$

Последњих деценија четрнаестога века у „земљама“ Соли и Усора уздигла се још једна нова снажна племићка лоза, Златоносовић чији су се поседи протезали одЗворника до Сребреникана Мајевици. ${ }^{34}$ Златоносовићи су, како је уверен Павао Анђелић, огранак Тихорадића. ${ }^{35}$ Колико је ова породица ојачала и стекла углед види се по томе што се сроднички везивала са најугледнијим племићким породицама. Златоносовић, чије име није запамћено, оженио се сестром обласног господара херцега Хрвоја Вукчића, једног од најмоћнијих босанских феудалаца свога времена. Истраживачи нису дошли до имена овога брачног пара, али је на цео род Златоносовића скренула пажњу судбина два њихова сина - Влађа и Стипана који су заробљени или погинули у Косовској бици 1389. године.

Твртко I „По милости Божијој краљ Србљем, Босни и Поморју и Западним странама““, ${ }^{36}$ крунисан у Милешеви, као краљ Срба и владар са највишим владарским звањем тога времена испунио је владарску дужност тако што је на Косово поље послао своју војску сакупљену из целе његове државе којом је командовао велики војвода Влатко Вуковић. Као потомак

28 Пристави су били угледни племићи који су уживали ,јавну веру“, опште поверење, сведочили су да су споразуми потписани, и који су у неку руку гарантовали да ће потписани споразуми у владарским повељама бити испуњени, јер истовремено уживали поверење владара и оних страна које су са владарем склопили споразум и преузели одређене обавезе.

29 Анђелић, 171.

30 Анђелић, 171.

31 Казанац је био представник државне управе и бринуо се о томе да се у управној јединици жупи редовно убирају владарски приходи, ; Милош Благојевић, Српска државност у средњем веку, Београд, 2011, 23.

32 Анђелић, Исто, 171.

33 Исто, 171.

34 Мргић, 95.

35 Анђелић, 167.

36 Сима Ћирковић, Историја средњовековне босанске државе, Београд, 1964, 137. 
изумрле лозе Немањића он је, како каже Милош Благојевић, краљ Твртко I „преузео на себе најтежу обавезу да брани Србе и српске земље од страних завојевача, па је послао своју војску на Косово 1389. године, сматрајући да то није само борба између кнеза Лазара и емира Мурата, већ да тамо рат против Турака води његово краљевство.“37 У војсци којом је у Косовској бици командовао Влатко Вуковић било је доста ратника из Усоре и Соли које је предводило њихово племство.

Међу онима који се нису вратили са Косова били су браћа Влађ и Стипан Златоносовић, сестрићи херцега Хрвоја Вукчића. После Ангорске битке прочуло се да су они живи, да су у ропству у Азији. ${ }^{38}$ Кнез Вукашин и Вукмир Златоносић почетком 1402. године преузели су дипломатску акцију тако што су „послали свога слугу Драгића великом војводи Хрвоју, а овај га је упутио Дубровчанима. Молио их је да у Цариграду испитају гласине о његовим нећацима - Влађу и Стипану, што су они и обећали. “39 Нема потврде да је дипломатска акција Дубровчана уродила плодом.

Златоносовићи су у време Српске деспотовине били верни деспоту Ђурђу, на што је попреко гледао босански краљ Твртко II. Године 1430. краљ Твртко II је ратовао са Златоносовићима, после тога сукоба губи се историјски траг последњег великаша из овога рода, Вукашина Златоносовића, за кога се претпоставља да је погинуо у или је погубљен у овом сукобу, после чега се у историјским изворима не помиње ова племићка лоза. ${ }^{40}$

Род Дињичића јавља се у историјским изворима крајем четрнаестога века. Павао Анђелић је уверен да Дињичићи воде порекло од Треботића. ${ }^{41}$ ИмамишљењадасуДињичићи родбинскибилиблискиЗлатоносовићима. ${ }^{42}$ Презиме овог рода изведено је из имена њиховог претка жупана Дињице које се јавља у историјским изворима из 1378. године. ${ }^{43}$ Жупан Дињица имао је четири сина: жупана Драгишу, војводу Ковача, кнеза Владислава и кнеза Павла. ${ }^{44}$ Син жупана Ковача, војвода Петар Ковачевић био је вазал деспота Ђурђа. У једном крсташком походу против Турака који су 1443. године организовали Угри, учествовао је и деспот Ђурађ, а у саставу Ђурађеве војске било је 600 до 700 коњаника из Подриња које је предводио

37 Благојевић, 295-296.

38 Мргић, 94; Анђелић, 168.

39 Мргић, 94; Анђелић, 168.

40 Сима Ћирковић, Противречности балканске политике, Историја српског народа II, 235; Анђелић, 160; Мргић, 119.

41 Анђелић, 65.

42 Родословне таблице и грбови српских династија и властеле, приредио Душан Мрђеновић, Београд, 1991, 177-178.

43 Анђелић, 165.

44 Анђелић, 155-156. 
војвода Петар Ковачевић..$^{45}$ у једном тренутку војвода Петар Ковачевић окренуо је леђа деспоту Ђурђу, прешао на страну босанског краља Твртка II и заузео Сребреницу. Убрзо је Сребреницу преузела деспотова војска, а у том сукобу погинуо је Петар Ковачевић. ${ }^{46}$

Петров млађи брат кнез Твртко Ковачевић погубљен је 1463. године када је султан Мехмед II Освајач заузео поседе Ковачевића у Подрињу. О његовој смрти оставио је сведочење Константин Михаиловић из Островице који је био војник у турској војсци: „И приспели смо у једну земљу босанскога кнеза који се звао Ковачевић, и изненадно нападнут, покорио се цару. А цар је потом наредио да се овај погуби. А онда је кренуо у краљевску земљу и опколио је најпре град Бобовац. Са собом није имао топова, па је наредио да се одмах пред градом лију и овим топовима је освојио град. “47

Погубљење Твртка Ковачевића - Дињичића, господара Подриња на левој обали Дрине са Сребреницом у средишту у време турског освајања Босне 1463. године, значио је крај не само ове, него и свих племићких породица ,земаља“" Усоре и Соли. ${ }^{48}$

Као и његови преци, претходници из династије Немањића, као и његов брат Милутин, и краљ Драгутин Немањић, са синовима Владиславом и Урошицом, подигао је многе цркве и манастире. Чинио је све да учврсти православну веру у новоприпојеним деловима своје државе, у данашњој источној и северној Босни. Њему и његовим синовима српски летописи и изузетно снажно народно предање приписују градњу већег броја богомоља међу којима су манастири Озрен, Папраћа, Ломница, Тавна, Гостовић (Удрим), Возућа и Липље. ${ }^{49}$ Истинитост народног предања потврдили су и неки историчари, а међу њима и Иларион Руварац. ${ }^{50}$ Ови манастири су током турске владавине разарани, а онда су како мисле Миленко С. Филиповић и Ђорђе Мазалић обнављани на старим темељима или грађени изнова у шеснаестом веку, после поновног успостављања Пећке патријаршије ${ }^{51}$ што је и прихваћено у науци. ${ }^{52}$ Уверење да су православни

45 Спремић, 278; Мргић, 124.

46 Спремић, 46.

47 Константин Михаиловић из Островице, Јаничареве успомене или турска хроника, Београд, 1986, 140-141; Анђелић, 166; Мргић, 124.

${ }^{48}$...Владимир Ћоровић, Историја Срба, други део, Београд, 1989, 95; Анђелић, 165; Мргић, 132.

49 Епископ зворничко-тузлански Лонгин, Улога српског-православног свештенства Зворничко-тузланске епархије у прошлости, Споменица СПЦ, 35; Мргић, 61.

50 И. Руварац, Нешто о Босни, Дабарској и Дабробосанској епископији и о српским манастирима у Босни, Годишњица Чупићеве задужбине, књ 2, 1878, 240-261.

51 Мргић, 61; Др М. С. Филиповић и Ђ. Мазалић, Манастир Озрен, др М. С. Филиповић и Ђ. Мазалић, Црква Ломница у Босни, Споменик, САНУ, 1961, 89-156.

52 Борис Нилевић, Српска православна ирква у БиХ до обнове Пећке патријаршије, Сарајево, 1990, 144-152. 
манастири Североисточне Босне грађени у шеснаестом веку умногоме је пољуљано после истраживања Здравка Кајмаковића који је понудио доказе да су неки од тих манастира грађени пре доласка Турака. ${ }^{53}$

О животу српског православног народа, њеног племства и свештенства у „земљама“ Усора и Соли непосредно су посведочили и хришћански надгробни споменици, откривени 13. децембра 2002. године у темељима Атик џамије у Бијељини, која је била срушена у рату 1993. године, а девет година касније почела је њена обнова. У време припремања терена за нове темеље муслиманске богомоље, у старим темељима били су узидани хришћански надгробни споменици. Откривени су остаци 23 надгробника из друге половине четрнаестог и прве половине петнаестога века на којима су били уклесани ћирилични натписи на старом српском језику. Ово је уједно археолошко налазиште са највећим бројем надгробних натписа у Босни и Херцеговини. Радови на обнављању џамије су прекинути на петнаест дана, а откривени споменици препуштени су археологу мр Мирку Бабићу, директору Музеја Семберије у Бијељини. ${ }^{54}$ Вадећи из темеља џамије српске средњовековне надгробне споменике, археолози су имали прилике да утврде и старост Атик џамије. ${ }^{55}$

Грађевински материјал од кога је сазидана Атик џамија скупљан је са српских православних гробаља и одсрпских богомоља, не само из Бијељине него и из шире околине. Узимани су пре свега надгробни споменици, који су затим на градилишту разбијани, и обликовани према потреби нове грађевине. На некима од тих надгробника сачували су се натписи који на најбољи начин сведоче о српском присуству у овим пределима. На тај начин „својим садржајем бијељински старосрпски натписи откривају не само имена покојника, већ и њихово порекло, откривају постојање цркве као заупокојене задужбине, бележе попове, монахе. Иако су претрпели знатна оштећења првобитног изгледа, уочава се разноврсност облика, од масивне монолитне плоче, преко нижег или вишег стуба са врхом на две воде, до такозваних слемењака, који подражавају облик куће са кровом на две воде. Начињени су од сличног грубо обрађеног пешчара,

53 Здравко Кајмаковић, Око проблема датащије православних манастира у Сјевероисточној Босни са посебним освртом на Папраћу, Наше старине, 13, 1972, 149-171.

54 Мирко Бабић и Гордана Томовић, Старосрпски натписи из Бијељине, Мешовита грађа - Miscellanea - Нова серија, Књ. XXII, Београд 2004, 81-82.

55 Атик џамија је грађена и дограђивана у више фаза. Две најстарије фазе трајале су од 1580. до 1688. године. У време аустријско-турских ратова ове пределе запосели су Аустријанци и 1716. године претворили је у римокатоличку цркву. Трајало је то до 1739. године, када је овај део Босне поново потпао под турску власт. Минарет је такође више пута дограђиван. На месту где је, можда, некада био дрвени минарет 1758 сазидан је камени, затим је 1894. и 1912. зидан нови од цигле и бетона, Бабић - Томовић, Старосрпски натписи из Бијељине, 81-82. 
сивкасто-окер или ружичасте боје. Различито компоновање натписа, облици слова и општи изглед натписа-епиграфски дуктус, одају различито време и различите писаре и клесаре. “56

Посебну вредност представља споменик Белосава Лучића из треће или четврте деценије петнаестог века, који је био ктитор. На свом поседу, на „својој племенитој баштини“ подизао је цркву у самој Бијељини, али завршетак богомоље није дочекао, предухитрила га је смрт. У тој цркви је као ктитор био сахрањен, а надгробник су му подигли синови. ${ }^{57}$ „Од 12 натписа“", како каже Јелена Мргић, „занимљив је онај Драгосава Болесалића који је писао поп Богела Кучевац. На основу морфолошке анализе писма истраживачи су датирали споменик у крај 14. века. На другом натпису из истог периода помиње се „раб Теоприл“, што је вулгаризовани облик црквеног имена Теофил. Забележено је име још једног монаха- „раб божији Георгије, а назван Драг(о)слав Бого(пи)сац“, коме су синови подигли споменик... Изражена је претпоставка да се у селу Попови - Звониш селиште (1548), односно Попови - Прокаи Бијељина $(1600 / 04)$ налазила православна црква с манастиром о коме сведоче ови натписи. “58

Јово Л. Бајић*

Кључне речи: Босна, Дивошево јеванђеље, Тихорадићи, Златоносовићи, Ковачевићи, Усора и Соли

Jovo L. Bajić

THE NOBILITY OF NORTH-EAST BOSNIA

The article on the medieval nobility of North-East Bosnia draws attention to those noble families who were particularly adamant in their effort to preserve the Orthodox Christian faith and their national identity. Among these, the most prominent were the Tihoradić, lord Hlap and his descendants, the Zlatonosović and the Kovačević family.

56 Бабић - Томовић., 83.

57 Бабић - Томовић, 81-104.

58 Мргић, 194.

*1jeljen@gmail.com 